\title{
ComPlexUs
}

Bairoch, A. V

Barnard ,A.M.L. 87

Danchin, A. 61

Francois, P. 71

Hochstrasser, D.F. 79

Salmond, G.P.C. 87

Sanchez, J.-C. 79

Scherl, A. 79

Schrenzel, J. V, 71

\section{SUBJECT INDEX VOL. 2, NO. 2, 2004-05}

Bacteria 79

Bacterial communication 87

Bacterial signalling 87

Bioinformatics 79

Cell density-dependent regulation 87

Comparative genome hybridization 71

Complexity 79

Data management 79

Dissymmetry 61

Gene expression 71

Gene regulation 87

Gene transfer, horizontal 61

Genomotyping 71

LuxR 87

LuxI 87
Microarray 71

$\mathrm{N}$-Acyl homoserine lactone 87

Oligoarray 71

Pheromone 87

Phylogeny 61

Prokaryotes 71

Proteomics 79

Quorum sensing 87

Replication 61

Specificity 71

Staphylococcus aureus 71

Transcription profiling 71

Translation 61

(C) 2005 S. Karger AG, Basel 